\title{
War and Peace: A Methodology to Formulate a Contemporary Jewish Approach
}

\author{
Elliot N. Dorff
}

Received: 17 August 2012 / Accepted: 20 August 2012 /

Published online: 13 September 2012

(C) Springer Science+Business Media B.V. 2012

The only times before 1948 when Jews ruled themselves and made their own decisions as a nation as to when to go to war and how to wage it were between c. 1250 B.C.E. and 586 B.C.E. (the conquest of Canaan and the First Temple period) and between 165 B.C.E. and 63 B.C.E. (the Maccabean period). Jewish sources on war are therefore either very old or only theoretical, without a base in the actual experience of deciding to go to war and the strategies to use. Jews, of course, participated in the armed forces of the nations in which they were living, and, in countries founded on Enlightenment principles, they did so as full citizens. It was not the Jewish tradition, however, that governed those wars, either in the grounds for going to war or the rules of conduct during the war. Now, however, with the establishment of the modern State of Israel and its unfortunate surfeit of experience with war, Jews are very much occupied with those decisions. To what extent, and in what way, can the Jewish tradition apply to those decisions, if at all?

This is parallel to the problem that Jews have in gaining guidance from their tradition on any issue where the science, technology, or social or political conditions have changed radically. There are only four sources in the Jewish tradition, for example, that contemplate that people can have any effect on sustaining life when a person is dying, and none of those sources parallels the conditions in modern hospitals or hospices. Any reasonable Jewish treatment of whether and, if so, when to remove life support must therefore take those sources into account but also go beyond them to locate the underlying Jewish concepts of life and death and the role of medicine in our lives. In several places ${ }^{1} \mathrm{I}$ have

\footnotetext{
${ }^{1}$ See, for example, the Appendix to my book, Matters of Life and Death: A Jewish Approach to Modern Medical Ethics (Philadelphia: Jewish Publication Society, 1998), pp. 395-417, and, in a fuller treatment of the method I am proposing to moral issues generally, the Appendix to my book, Love Your Neighbor and Yourself: A Jewish Approach to Modern Personal Ethics (Philadelphia: Jewish Publication Society, 2003), pp. 311-344. See also my article, "Applying Jewish Law to New Circumstances," in Teferet Leyisrael: Jubilee Volume in Honor of Israel Francus, Joel Roth, Menahem Schmelzer, and Yaacov Francus, eds. (New York: Jewish Theological Seminary, 2010), pp. 189-199.

E. N. Dorff $(\square)$

Department of Philosophy, American Jewish University, 15600 Mulholland Drive, Los Angeles, CA 90077-1599, USA

e-mail: elliot.dorff@sbcglobal.net

E. N. Dorff

e-mail: edorff@ajula.edu
} 
articulated how this methodology works in several areas of medical, social, and personal ethics that involve significantly new circumstances in our time, and in this essay I will apply that methodology to peace and war.

Professor Walzer, responding to the same problem that motivates me - namely, the dearth of sources in the Jewish tradition that come from actual experience of making decisions about war - suggests that Jews do what we have often done, namely, learn from the non-Jewish world, in this case from Christian just war theory. Precedents for borrowing from other cultures abound in both Jewish law and Jewish thought, so in suggesting a different approach, I am not denying the Jewish authenticity of doing what he suggests. The problem with that, though, is that at some point one wants to know what makes the borrowed material Jewish, especially if it presumes concepts or values significantly different from those of the classical Jewish tradition. In this case, Professor Walzer would undoubtedly argue that the values underlying Christian just war theory are Jewish values too, and by and large he would be right about that. So I too would want to learn from what Christian thinkers have produced on this issue. I would want to do that, though, only after spelling out the Jewish concepts and values relevant to war and peace so that in borrowing whatever Jews learn from Christian just war theory we are very much aware of the Jewish lens through which we evaluate what to borrow from it and what not.

My thesis, then, is that to articulate an authentic Jewish ethic of war for modern times one must do "depth theology," in which one considers the ultimate Jewish understandings of God and humans, including the degree to which they are understood to be prone to war, the role of war in their character and in their activities, and, on the other hand, their penchant and hope for peace. One must also consider how peace is construed in the first place. In carrying out this project one must look not only at whatever sources exist within the Jewish tradition, but also at modern Jewish sources. One must take seriously, for example, what the State of Israel has drawn from the Jewish tradition in defending itself. This includes documents like the Code of Ethics of the Israel Defense Forces and the actual policies and practices of the State of Israel in waging war. It is to accomplish these tasks to which this essay is devoted.

\section{War and Peace in the Nature of God}

Many Jews do not like to confront this fact, but God is depicted in the Bible as a God of war. The Song of the Sea, for example, includes these lines that the Israelites sang after crossing the Reed Sea:

Pharaoh's chariots and his army He has cast into the sea; and the pick of his officers are drowned in the Sea of Reeds... Your right hand, O Lord, glorious in power, Your right hand, O Lord, shatters the foe! In Your great triumph You break Your opponents; You send forth Your fury, it consumes them like straw....You made Your wind blow, the sea covered them; they sank like lead in the majestic waters....In Your love You lead the people You redeemed; in Your strength You guide them to Your holy abode. The peoples hear, they tremble; agony grips the dwellers in Philistia. Now are the clans of Edom dismayed; the tribes of Moab - trembling grips them; all the dwellers of Canaan 
are aghast. Terror and dread descend upon them; through the might of Your arm they are still as stone, till Your people cross over, O Lord, till Your people cross, the ones You have ransomed...The Lord will reign for ever and ever! ${ }^{2}$

A check of the Biblical concordance indicates that the phrase "Adonai tz'va'ot," "Lord of armies," appears 244 times in the Hebrew Bible, and together with similar phrases such as "Adonai elohei tzva'ot," the Lord, God of armies," the description of God as a God of war appears 286 times in the Hebrew Bible. God, in fact, not only does battle Himself; he commands the Israelites to go to battle to conquer the Canaanite nations. ${ }^{3}$ With regard to Amalek, God tells Moses: "Inscribe this in a document as a reminder, and read it aloud to Joshua: I will utterly blot out the memory of Amalek from under heaven!"...The Lord will be at war with Amalek throughout the generations." King Saul later loses his throne for not killing all the animals of Amalek as well as the people. ${ }^{5}$ Furthermore, messianic visions of future times in the Bible regularly include God waging war with Israel's enemies and even with the parts of nature that served them in order to bring about a promised state in which the Israelites would rule themselves and there would be peace and justice in the world. ${ }^{6}$

This bellicose depiction of God is clearly not the God of love and kindness that normally comes to mind when Jews think about God, but it is very much part of the Biblical conception of God. At the same time, there are other sources in the Bible that serve as the basis for the belief in a God of compassion and peace. So, for example, the Torah, in a passage used often in the liturgy, quotes God describing Himself as follows:

The Lord passed before him [Moses] and proclaimed: "The Lord! The Lord! A God compassionate and gracious, slow to anger, abounding in kindness and faithfulness, extending kindness to the thousandth generation, forgiving iniquity, transgression, and sin; yet He does not remit all punishment, but visits the iniquity of parents upon children and children's children, upon the third and fourth generation. ${ }^{7}$

In a passage cited later by the Rabbis to assert that God desires peace, the Lord says to Gideon: "'You will have peace; have no fear, you shall not die.' So Gideon built there an altar to the Lord and called it 'Adonai Shalom' ('The Lord of Peace')." 8 Based on this verse the Rabbis say: "Great is peace, for all blessings are contained in it....Great is peace, for God's name is peace [citing Judges 6:24, just quoted]."9 Furthermore, God's blessings of the people Israel repeatedly include a blessing of peace, perhaps most notably in the blessing he instructs Aaron and his descendants to use in blessing the Israelites: "May the Lord bless you and protect you! May the Lord deal kindly and graciously with you! May the Lord bestow His favor upon you and

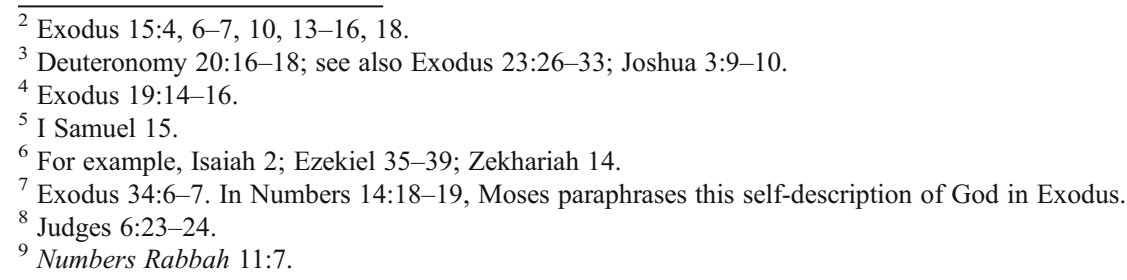


grant you peace." ${ }^{10}$ Similarly, peace as well as strength is God's blessing in this passage from Psalms used often in the liturgy: "May the Lord grant strength to His people; may the Lord bless His people with peace."11 Finally, the Psalmist asserts that those who follow God's laws will attain peace: "Those who love Your teaching enjoy well-being [literally, "great peace," shalom rav]; they encounter no adversity,"12 Similarly Proverbs: "My son, do not forget my teaching, but let your mind retain my commandments, for they will bestow on you length of days, years of life and well-being (peace, shalom)...Her ways are pleasant ways, and all her paths peaceful. She is a tree of life to those who grasp her, and whoever holds on to her is happy."13

Thus any formulation of a Jewish approach to war and peace must take into account that God as depicted in the traditional sources is the author of both war and peace. Isaiah said this most succinctly: "I [God] from light and create darkness, I make peace and create evil, I the Lord do all these things.",14

\section{The Nature of Human Beings}

If God as described in Jewish sources has conflicting tendencies toward both war and peace, human beings do likewise. This begins with the tradition's insistence, as articulated in the Garden of Eden story, that human beings know the difference between good and evil and have the free will - and therefore the responsibility - to choose between them. ${ }^{15}$ In contrast to Christian interpretations of that story that use it to assert a doctrine of Original Sin, such that human beings cannot control the sinful inclinations that they have and therefore need a supernatural intercessor, Jesus, to redeem them from sin, the Jewish tradition used that story to claim the opposite - that people know the difference between right and wrong, they have the free will and ability to choose between them, they therefore have the responsibility to choose correctly, and they can be morally and legally held liable for their choices. That is why it makes sense for the Torah to prescribe, by traditional count, 613 commandments $^{16}$; if people either could not obey them or if they were hard-wired to obey them, commanding them to do some things and refrain from others and then rewarding or punishing them for their choices would make no sense whatsoever. Indeed, the Torah's recognition of the fact that human beings can choose to obey or disobey the commandments is the reason that it articulates a plethora of reasons why the Israelites should obey so that they are motivated to do so; I describe those multiple motivations elsewhere. ${ }^{17}$

\footnotetext{
${ }^{10}$ Numbers 6:22-27.

${ }^{11}$ Psalms 29:11.

12 Psalms 119:165.

${ }^{13}$ Proverbs 3:1-2, 17-18. The subject of the chapter in Proverbs is wisdom, but the last two of these verses are used as we put the Torah back in the ark, and so the liturgist has the congregation think of the subject as the Torah's laws rather than those of generic wisdom.

${ }^{14}$ Isaiah 45:7.

${ }^{15}$ Genesis 3 generally, esp. verses 5 and 22 .

${ }^{16}$ B. Makkot 23b. See also B. Yevamot 47b; B. Nedarim 25a; B. Shevu'ot 29a.

${ }^{17}$ See Elliot N. Dorff, For the Love of God and People: A Philosophy of Jewish Law (Philadelphia: Jewish Publication Society, 2007), Chapter Four (pp. 131-188).
} 
The Rabbis later describe the human moral situation as an eternal battle between our yetzer ha-tov and our yetzer ha-ra. The literal translation of those terms is, respectively, "the good inclination" and "the bad inclination," but one Rabbinic source makes it clear that our use of the yetzer ha-ra is not always bad; in fact, without it, some very important and good things would not happen in life:

"And God saw everything that He had made, and behold, it was very good." [What made the sixth day very good, in contrast to the earlier five that were described as only "good"?] God created the good impulse and the evil impulse. But is the evil impulse "very good"? Yes, for were it not for the evil impulse, a man would not build a house, marry a wife, beget children, or conduct business affairs. ${ }^{18}$

Thus the terms, yetzer ha-ra and yeter ha-tov, are more accurately translated as "the self-serving (or self-regarding) inclination" and "the other-serving (or altruistic) inclination." They are called "good" and "evil" because by and large when we do things for our own good alone we may harm others, while if we do things for others they are usually good acts. But that is not always so, for, as the rabbinic comment just cited indicates, some self-serving actions are both important and good, and, conversely, some other-regarding actions, especially when taken to an extreme, can be morally bad, as the following Rabbinic story indicates:

When the charity collectors saw Elazar Ish Biratha, they would hide from him, for otherwise he would give them everything he had. One day he went to the market to provide a dowry for his daughter. The charity collectors saw Elazar and hid from him. He, however, ran after them and said to them: "I adjure you, tell me what you are collecting for?" They said to him, "We are collecting for an orphan boy and an orphan girl [so that they may marry]." He said to them: "By the Temple Service [the form of making an oath]! The orphans take precedence over my daughter." He took all that he had and gave it to them. He kept, though, one $z u z$ [a small denomination of money], and with it he bought wheat, which he brought home and placed in his storehouse. His daughter asked him, "Father, what did you get?" He said to her, "All that I bought I placed in the storehouse." When she went to open the door to the storehouse, she saw that the storehouse was filled with wheat so that it was bursting out of the door lock, so much so that the door would not open [because its openings on the top and bottom were stuffed with wheat]. Elazar's daughter went to the house of study and said to him, "Come and see what your Beloved [God] did for you!" He said to her, "By the Temple Service! This wheat is consecrated [and hereby given to the Temple], and you must only draw from it along with the other poor of Israel."19

The Torah asserts that our self-regarding impulse is "evil from our youth." 20 Undoubtedly noting how self-centered infants are, the Rabbis maintain both that moral choices are a distinctly human capability and that our moral faculties grow over time:

\footnotetext{
${ }^{18}$ Genesis Rabbah 9:7.

${ }^{19}$ B. Ta'anit $24 \mathrm{a}$.

${ }^{20}$ Genesis 8:21.
} 
There is no evil impulse in animals....The evil impulse [in humans] is thirteen years older than the good impulse. It exists from the time of a person's emergence from his mother's womb; it grows with him and accompanies him through life. It begins to desecrate the Sabbath, to kill and to sin sexually, but there is nothing [within him] to prevent it. After thirteen years the good impulse is born. When he desecrates the Sabbath, it warns him, "Good-for-nothing! Behold the Torah says, "Every one who profanes it surely shall be put to death" (Exodus 31:14). If he thinks of committing murder, it warns him, "Good-for-nothing! Behold the Torah says, "Whoever sheds a person's blood, by man shall his blood be shed" (Genesis 9:6). If he proposes to commit a sexual sin, it warns him, "Good-for-nothing! Behold the Torah says, "Both the adulterer and the adulteress shall surely be put to death" (Leviticus 20:10)....

Adulthood, then, is a constant struggle between our self-regarding and altruistic inclinations. By and large, we must do our best to enable our altruistic inclinations to motivate our actions, and simultaneously we must fight against our self-regarding inclinations, but, as the sources cited above indicate, there are limits to that, for sometimes we need to do that which is in our own self-interest and sometimes doing things for others is so extreme that we neglect our duties to ourselves and our family. Ultimately, living life morally requires that we learn how to balance these inclinations, activating each in its appropriate venue and to its appropriate degree. This even includes, according to Ecclesiastes, learning when to wage war and when to seek peace:

A season is set for everything, a time for every experience under heaven:

A time for being born and a time for dying,

A time for planting and a time for uprooting the planted;

A time for slaying and a time for healing,

A time for tearing down and a time for building up...

A time for ripping and a time for sewing,

A time for silence and a time for speaking;

A time for loving and a time for hating,

A time for war and a time for peace. $^{22}$

\section{The Duty to Take Care of Oneself and Others}

Before turning to the Jewish sources that address war and peace directly, it is important to understand the underlying concepts and values that motivate those sources. The most fundamental of those is that God, as Creator of heaven and earth,

\footnotetext{
${ }^{21}$ Avot D'Rabbi Natan 16.

${ }^{22}$ Ecclesiastes 3:1-3, 7-8.
} 
owns everything on earth, including every human being. This is reflected in the phrase describing God as koneh shamayim va'aretz, ${ }^{23}$ usually translated as "Creator of heaven and earth," but where "heaven and earth" is a merism, a common feature of Biblical Hebrew, where the ends of a spectrum refer to everything in between as well, and where the verb, koneh, means not only "creator" but "owner." The same conviction that God owns everything and everyone on earth is articulated in such verses as these: "Mark, the heavens to their uttermost reaches belong to the Lord your God, the earth and all that is on it!" and "The earth is the Lord's and all that it holds, the world and its inhabitants.",24

This derives from the underlying assumption that the creator of something owns it, something less clear to us moderns because the Industrial Revolution has divided the creation of most things among many people, none of whom own it, but the connection between creation and ownership is still evident in intellectual property through patents and copyrights.

As Owner of us, God can and does insist that we take care of ourselves. This first means that although we may remove life support systems for the benefit of a dying patient so as not to prolong the process of dying, we may not commit suicide or assist others in doing so, ${ }^{25}$ and we may not intentionally injure ourselves. ${ }^{26}$

Furthermore, we must avoid endangering our lives unnecessarily. Moses Isserles (1525-1572), whose comments on Joseph Karo's code of Jewish law, the Shulhan Arukh, explain where Ashkenazic (northern European) practice adds to, or differs from, Sephardic (southern European) practice, summarizes the rules in Jewish law that require us to avoid danger. In quoting him, I will indicate which earlier sources he is invoking:

One should avoid all things that might lead to danger because endangering one's life is more strictly prohibited than [other] prohibitions [B. Hullin 10a]. One should be more concerned about [risking[ a possible danger to life than possibly [risking a violation] of a prohibition. Therefore the Rabbis [of the Talmud] forbade walking in any place of danger, as, for example, under an inclined wall [B. Rosh Hashanah 16b, B. Ta'anit 20b], or alone at night [M. Avot (Ethics of the Fathers) 3:5], and they similarly forbade drinking water from the rivers at night [lest one not see what one was drinking or be attacked in the process] or resting one's mouth on a water pipe to drink, because these activities are possibly dangerous... They furthermore wrote that one must flee a city when there is a plague in it, and one must do this at the beginning of the plague and not at its end [i.e., when it has been around awhile]. And all these

\footnotetext{
${ }^{23}$ Genesis 14:19, 22.

${ }^{24}$ Deuteronomy 10:14; Psalms 24:1.

${ }^{25}$ Genesis 9:5-6 seems to make this ban clear, but based on the suicide of King Saul (1 Samuel 31:3-4), later Jewish sources make exceptions to this ban in the case of martyrdom or potential danger to others, and some even consider the permissibility of suicide in a case of extreme pain and suffering. See Basil Herring, Jewish Ethics and Halakhah for Our Time (New York: Ktav and Yeshiva University Press, 1984), pp. 6790 for a range of Orthodox positions on this and Elliot N. Dorff, Matters of Life and Death: A Jewish Approach to Modern Medical Ethics (Philadelphia: Jewish Publication Society, 1998), pp. 176-220 for an official Conservative position on this, validated by the Conservative Movement's Committee on Jewish Law and Standards.

${ }^{26}$ M. Bava Kamma 8:6.
} 
directives are because of the danger involved, and those who take care of themselves will distance themselves from them. And it is forbidden to rely on a miracle or to put one's life in danger. ${ }^{27}$

Obviously, life is full of danger, and presumably by creating us as we are God intends that we live our lives using the capacities that God has built in to us. We are not supposed to cloister ourselves to avoid all possible risks. That degree of caution is unwarranted. Which risks, then, is permissible to take? The general rule that the Rabbis articulate is that one may take those risks that people normally take in their lives. ${ }^{28}$ In our day that would include such things as driving a car, which, though potentially the cause of injury and even death, people commonly do and often need to do to earn a living. The Rabbis' criterion would even permit recreational activities like skiing, where there is no necessity to engage in the activity but where, if done with proper training and precautions, the risks of injury or death are not great. Given what we know about the addictive effects of smoking and hallucinatory drugs, however, most contemporary rabbis have ruled that Jews may not smoke or take hallucinatory drugs.

We also may not injure others. The Mishnah spells out the remedies owed the victim of an injury: "He who injures a person is [monetarily] liable on five counts: for the injury itself, for pain, for healing, for loss of time, and for insult." ${ }^{\prime 29}$ The Mishnah then describes how each of the five remedies is to be calculated, and later Jewish law adds considerably to this discussion of the various ramifications of the ban on injuring others.

It is as if God is the owner of an apartment that we are renting: we have fair use of the apartment during our lease, but we may not destroy the apartment or damage it beyond the results of normal use. Similarly, we have the right to engage in normal activities during our lease on life, but our fiduciary duty to maintain God's property requires that we refrain from injuring ourselves and others, including avoiding activities that are so dangerous that most people do not do them.

Moreover, we have a positive duty to maintain our bodies through proper diet, exercise, hygiene, and sleep. Most contemporary people would think of that duty in pragmatic terms - that we must maintain our health in order to feel good, live a long life, get a good job, have many friends, and avoid pain and suffering. Maimonides, a physician as well as a rabbi and philosopher, sees that form of thinking as inappropriate; one instead should maintain one's body so that one is in a condition to serve God:

He who regulates his life in accordance with the laws of medicine with the sole motive of maintaining a sound and vigorous physique and begetting children to do his work and labor for his benefit is not following the right course. A man should aim to maintain physical health and vigor in order that his soul may be upright, in a condition to know God.... Whoever throughout his life follows this course will be continually serving God, even while engaged in business and even during cohabitation, because his purpose in all that he does will be to

\footnotetext{
${ }^{27}$ S.A. Yoreh De'ah 116:5 [gloss].

${ }^{28}$ B. Shabbat 129 b.

${ }^{29}$ M. Bava Kamma 8:1.
} 
satisfy his needs so as to have a sound body with which to serve God. Even when he sleeps and seeks repose to calm his mind and rest his body so as not to fall sick and be incapacitated from serving God, his sleep is service of the Almighty. ${ }^{30}$

God's ownership of our bodies also means that we have a duty to save others when they are in danger. This is very much at odds with American law. Until recently, when states passed "Good Samaritan laws," anyone who sought to help someone in distress could actually be sued if any injury occurred in the attempted rescue. Now the rescuer is unlikely to face a lawsuit for anything untoward that happens in the process of trying to rescue someone, especially if the rescuer used "reasonable" methods in the attempt. On the other hand, anyone who just ignores a cry for help is unlikely to be prosecuted, for a duty to rescue from a criminal act in progress or from a medical emergency exists only in ten states, and in most of those it is just a misdemeanor to ignore the person in distress even when the person would not endanger himself at all (by calling for medical or police help, for example). ${ }^{31}$ In contrast, based on "Do not stand idly by the blood of your neighbor" (Leviticus 19:16), the Rabbis ruled that "if a man sees his fellow drowning, mauled by beasts, or attacked by robbers, he is bound to save him." ${ }^{32}$ Each of us has the duty to preserve our own life and health as well, and so potential rescuers must call in the help of others, if necessary, to make sure that they do not put their own lives at too much risk. ${ }^{33}$ At the same time, Jewish law does require that one come to the aid of someone in distress.

In sum, then, a foundational conviction of Jewish law that will affect how the Jewish tradition understands war and peace is that our bodies belong to God and that we therefore have a duty to avoid injuring, much less killing, ourselves or others and that, conversely, we have a duty to promote the life and health of ourselves and others. These duties will clearly mean that a strong burden of proof will apply to any argument to go to war.

\section{Self-Defense for Individuals}

That burden of proof, however, can be met; the Jewish tradition is not pacifistic. The legal foundation for Jews going to war begins with the right to defend oneself from attack, a duty first announced in Exodus 22:1-2: "If a thief is seized while tunneling [under a wall for housebreaking], and he is beaten to death, there is no bloodguilt in

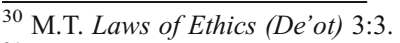

${ }^{31}$ For a recent listing of those state laws, see Eugene Volokh, "Duty to Rescue/Report Statutes," at http:// volokh.com/2009/11/03/duty-to-rescuereport-statutes (accessed 11/6/11).

32 B. Sanhedrin 73a. On the duty to rescue in Jewish law generally, see Aaron Kirschenbaum, "The Bystander's Duty to Rescue in Jewish Law," http://www.daat.ac.il/daat/kitveyet/assia_english/kirschenbaum.htm (accessed 11/6/11).

${ }^{33}$ In much the same way, as part of my training to become a Senior Life Saver in my teenage years, I was taught this mantra: "Throw, tow, row, go." That is, even those trained to rescue others in the water should endanger themselves as little as possible by first trying to help the drowning person by simply throwing the person something to hold on to without entering the water at all until a number of people can be summoned to help, thus diminishing the risks to everyone. If that is not possible, then throw the person a rope and pull the person to land. If that does not work, row out to the person so that you are not exhausted when you reach him or her, and only as a last resort do you swim out to the person to save him or her.
} 
his case. If the sun has risen on him, there is bloodguilt in that case." The Talmud concludes that "The Torah [thereby] says: If someone comes to kill you, kill him first." 34 The Torah in this passage probably means "the sun" literally, ruling that at night there is no liability for killing the intruder because one cannot see whether he or she intends to kill you or only to rob you but during the daytime there is liability if one overreacts to a robber who has no clear intention to kill. Later Jewish law, however, understood "If the sun has risen upon him" metaphorically to mean "if it is as clear to you as the sun that the intruder does not intend to act peacefully with you [and intends to injure or kill you], kill him, but if not, do not kill him," so that the issue is not the time of day but the perceived intention of the intruder, even if the robbery is at night. ${ }^{35}$ This puts a greater burden on the potential victim to make sure that his or her life is really at stake before killing the assailant. In the theater of war, one might presume that enemy soldiers want to kill you, but when policing occupied populations one cannot automatically presume that. This, of course, makes it very hard for Israeli soldiers to know what to do when stationed in the West Bank in our time.

Even when another person does not intend to kill you and it is simply unfortunate circumstances that require that you choose to save someone else's life or your own, you must choose your own:

Two people are traveling on a journey [far from civilization], and one has a pitcher of water. If both drink, they will both die, but if only one drinks, s/he can reach civilization. Ben Peturah taught: It is better that both should drink and die rather than that one should witness his/her companion's death. Rabbi Akiba came and taught: '...that your brother may live with you' (Leviticus 25:35) [implies] your life takes precedence over his/her life. ${ }^{36}$

One commentator, the Ritba, a Spanish commentator of the thirteenth century, suggests that Ben Peturah based his decision on Leviticus 19:18, "Love your neighbor as yourself," meaning that each person must make every other person a full equal, even in access to life. Most commentators maintain that Rabbi Akiba would have agreed with Ben Petura if both or neither of the travelers owned the jug, but Rabbi Akiba ruled as he did because he assumed that only one of them did. That person, Rabbi Akiba maintained, may not give up his or her own life by sharing the water because suicide is just as prohibited as murder. In this morally impossible situation, he was claiming, let the circumstances determine who drinks the water, even if it is just who happens to own the jug of water, and then let nature take its course so that the people involved do not have the moral burden of making a decision to commit either suicide or murder.

Another famous and controversial source affirms that one may not save one's own life and the lives of other innocent people by sacrificing the life of another person. The exception is if the person to be sacrificed has been found guilty of a capital offense - and even then it is not clear that one should give up that person's life to save others. The difficulty of this decision is evidenced by the differing opinions recorded

\footnotetext{
${ }^{34}$ B. Berakhot 58a, 62b; B. Yoma 85b; B. Sanhedrin 72a.

${ }^{35}$ B. Sanhedrin 72a; similarly J. Sanhedrin 8:8.

${ }^{36}$ B. Bava Metzia 62a.
} 
in the sources, which themselves are open to differing interpretations, and by the fact that the story appears in two differing forms. The first opinion in the first version is this:

Caravans of men are walking down a road, and they are accosted by non-Jews who say to them: "Give us one from among you that we may kill him; otherwise we shall kill you all." Though all may be killed, they may not hand over a single soul of Israel. However, if the demand is for a specified individual like Sheva, son of Bikhri, they should surrender him rather than all be killed. ${ }^{37}$

The first clause asserts the ultimate divine value of each human being. The inhabitants of the besieged city may not participate in the crime of murder as accessories by singling out any one of them, even though refusing to pick one of their number will mean the death of them all. The second clause asserts, however, that if the enemy singles out a person in the city who is himself liable for the death penalty anyway, as Sheva, son of Bikhri, was in the Biblical story in II Samuel 20, then the inhabitants should surrender him rather than all be killed. Handing him over may itself be construed as complicity in the crime, but it is a lesser degree of involvement because it was the enemy, and not they, who chose who should die and, in any case, he was independently liable for the death penalty. Even so, handing him over to the enemy, rather than executing him according to legal procedures, is only justified by the need to save everyone else.

In the second section of this source, however, Rabbi Judah maintains that the citizens of the city may save themselves even if the designated person is not liable for the death penalty:

Rabbi Judah said: When do these words apply [that they may hand over to the enemy only someone who is named and also liable for the death penalty like Sheva ben Bikhri] ${ }^{38}$ When he [the individual in question] is inside [the city walls] and they [the enemy] are outside. But if he is inside and they [the enemy]

\footnotetext{
37 J. Terumot 7:20; Genesis Rabbah 94:9.

${ }^{38}$ The reference of Rabbi Judah's question is unclear. If we follow the usual stylistic conventions, where the phrase "where does that apply" comes to narrow a previous ruling to make it more lenient, Rabbi Judah comes to limit the first opinion mentioned (the tanna kamma). Specifically, while the first opinion says that if the enemy does not designate a particular person nobody may be handed over, Rabbi Judah would say that that only applies if the enemy is still outside the city walls so that there is still a chance that they would all survive, but if the enemy has already managed to break into the city, someone may be handed over to save the rest since that is the only chance that any of them will be saved.

The problem with interpreting Rabbi Judah that way, though, is that if the enemy had not designated someone, how are the city dwellers to choose whom to hand over? Moreover, Rabbi Judah says that "he" may be handed over if the enemy is inside the city walls, which would seem to indicate that the enemy has designated someone.

This, then, leads us to interpret the first opinion and Rabbi Judah as we do here, namely, that the first opinion permits handing over only someone who is both designated by the enemy and also liable for the death penalty, while Rabbi Judah says that if the enemy designated someone and the lives of the rest of the city are at stake, the citizens may hand over the designated party even if he is not liable for the death penalty in order to save themselves. Under this interpretation, in the next generation, Rabbi Shimon ben Levi (Resh Lakish) in the next clause agrees with the first opinion, and Rabbi Yohanon agrees with Rabbi Judah. See Saul Lieberman, Tosefta Ki-Fshutah, Zeraim (New York: Jewish Theological Seminary of America, 1955), pp. 420-422 [Hebrew]; Elijah J. Schochet, A Responsum of Surrender (Los Angeles: University of Judaism, 1973), pp. 6-7; and David Daube, Collaboration with Tyranny in Jewish Law (New York: Oxford University Press, 1965), pp. 31-36.
} 
are inside, because he would be slain and they [the other city dwellers] would be slain, let them surrender him [that is, someone named by the enemy but not liable for the death penalty] so that not all of them will be slain.

Rabbi Judah is saying that if the enemy is still outside the city walls and therefore there is a chance that all the city dwellers will be able to outlast the siege and survive, they should not hand over any innocent party, even if the enemy named a specific person. In that situation, Rabbi Judah agrees with the first opinion above. But if the enemy has already broken inside the walls, such that everyone is in immediate danger of being slain, the city dwellers may hand over the named person, even if $\mathrm{s} / \mathrm{he}$ is not liable for the death penalty. In so doing, they are, of course, indirectly involved in causing the innocent person's death, but Rabbi Judah permits that degree of complicity when the objective situation makes it clear that the city dwellers would otherwise all die and when it is the enemy, and not they, who choose the one to die.

Normally, when a rabbinic source records an unnamed opinion and then a named one on the same issue, the former is understood to be the opinion of the majority and therefore the law. As a result, in the source we have been discussing, the law would be according to the first, anonymous opinion and not Rabbi Judah. The Jerusalem Talmud, however, adds two further sections that complicate matters further. The first is this:

Resh Lakish stated: [He may be surrendered] only if he is deserving of death as Sheva, son of Bikhri. Rabbi Yohanon said: Even if he is not deserving of death as Sheva, son of Bikhri. ${ }^{39}$

Resh Lakish is ruling in accordance to the unnamed opinion discussed above, and Rabbi Yohanon is ruling in accordance with Rabbi Judah. This is surprising on two grounds. First, it is Rabbi Yohanon himself who establishes the rule that the law is according to an anonymous Mishnah, ${ }^{40}$ and here he is disagreeing with it. Second, Rabbi Yohanon (c. 180-c. 279 C.E.) was the founder of the rabbinical academy in Tiberias and arguably the most important rabbi of his generation, and in his many disagreements with his brother-in-law, Resh Lakish, the opinion of Rabbi Yohanon was generally followed. ${ }^{41}$ In other words, if the general rules of authority are followed, there has been a shift in one generation in the accepted opinion on this issue such that it was no longer required that the person be culpable to justify giving him or her up to the enemy, as long as the enemy singled him/her out.

The fourth section of this source, however, dispels any sense of an emerging consensus:

Ulla, son of Qoseb, was wanted by the [non-Jewish] government. He arose and fled to Rabbi Joshua ben Levi at Lydda. They [troops] came, surrounded the city, and said: "If you do not hand him over to us, we will destroy the city."

\footnotetext{
39 J. Terumot $47 \mathrm{a}$.

${ }^{40}$ B. Shabbat $46 \mathrm{a}$.

${ }^{41} \mathrm{~B}$. Yevamot 36a, according to which the law is always according to Rabbi Yohanon when he argues with Resh Lakish except in three instances, and this is not one of those three. Rabbi Yohanon generally wins the day even though on two occasions (B. Ketubbot 54b, 84b), when confronted with the differing ruling by Resh Lakish, Rabbi Yohanon himself remarked, "What can I do when a rabbi of equal status disagrees with me?"
} 
Rabbi Joshua ben Levi went up to him, persuaded him to submit, and gave him up [to them]. Now Elijah [the prophet], of blessed memory, had been in the habit of visiting him [Rabbi Joshua], but he [now] ceased visiting him. He [Rabbi Joshua] fasted several fasts and Elijah appeared and said to him: "Shall I reveal myself to informers [betrayers]?" He [Rabbi Joshua] said: "Have I not carried out a mishnah [a rabbinic ruling]?" Said he [Elijah]: "Is this a ruling for the pious (mishnat hasidim)?" [Another version: "This should have been done through others and not by yourself."]

Since Ulla, son of Qoseb, apparently stood indicted by the government, all of the opinions discussed above would have instructed Rabbi Joshua to do what he did; this is not denied in this last section. He is nevertheless castigated because while ruling that way may fulfill the demands of justice, it is not exemplary. He instead, Elijah claims, should have been more pious in defending Ulla's life. That course of action, of course, would have endangered all the other inhabitants of Lydda, but this last source seems to demand such a risk; even if it seems quite certain that the troops would kill them all, Rabbi Joshua was obliged to try to save them all, including Ulla. He gave in much too easily. This position takes human equality to its logical extreme.

Another possible reading of Elijah's first response to Rabbi Joshua understands Elijah to be complaining not about Rabbi Joshua's actions, but about his failure to be bothered by the tragedy of the situation. It is possible, that is, that Elijah is simply demanding that Rabbi Joshua acknowledge that the choice is morally distressing and emotionally heartbreaking and that no matter what one does, there will be rough moral and emotional edges remaining.

The other version of Elijah's response, "This should have been done through others and not by yourself," would lead to yet a different conclusion. Rabbi Joshua's decision was the correct one, according to this reading, and it should be carried out. However, since it appears to lack piety, someone else should have made it. If we then ask who and why, the source is silent. It seems like a classic case of avoiding the responsibility a community leader has and should exercise. We can only guess that if someone else, presumably someone in a position of authority but less well known than Rabbi Joshua, had made the decision, then the community could still retain its sense of its own piety and that of its most visible leaders even while putting into effect what was just and what it had to do.

These sources thus affirm that one has both a right and a duty to defend oneself, but not at all costs. Ben Peturah would limit self-defense to those situations where you are not taking other innocent lives in defending your own, and Rabbi Akiba, according to many commentators, would agree with him if neither traveler or both owned the jug of water. The various positions on responding to an enemy demanding one of your own on pain of killing all of you exquisitely articulate the moral dilemma of saving yourself at the expense of other people, even those condemned to death by law. Rabbi Akiba rules that "your life comes first," but the story of the caravan severely limits that.

Unfortunately, Jews responding to morally excruciating situations in the Holocaust, such as whether to suffocate their own babies so that their hiding place will not be discovered, or whether to commit suicide so as not to reveal under torture the hiding place of others, provide concrete examples of the limits of the right and duty of 
self-defense. Similarly, in the modern State of Israel, not only police and soldiers, but ordinary citizens regularly confront situations in which Palestinian civilians might kill them. Under those circumstances, which security measures are, and which are not, legitimate as a matter of self-defense?

\section{War and Peace in Jewish Law}

When we now look at the few sources in the Jewish tradition that specifically deal with war, we find, first, a passage in the Torah that may well reflect its ethic of war during the First Temple Period, when Jewish rulers had the responsibility and power to decide whether to go to war and how to conduct it. The relevant passage is Deuteronomy 20-21, some of which I will reproduce below:

When you take the field against your enemies and see horses and chariots forces larger than yours - have no fear of them, for the Lord your God, who brought you from the land of Egypt, is with you. Before you join battle,...the officials shall address the troops, as follows: "Is there anyone who has built a house but has not dedicated it? Let him go back to his home, lest he die in battle and another dedicate it....Is there anyone who has paid the bride-price for a wife but who has not yet married her? Let him go back to his home, lest he die in battle and another marry her...."

When you approach a town to attack it, you shall first offer it terms of peace. If it responds peaceably and lets you in, all the people present there shall serve you at forced labor. If it does not surrender to you but would join battle with you, you shall lay siege to it; and when the Lord you God delivers it into your hand, you shall put all its males to the sword. You may, however, take as your booty the women, the children, the livestock, and everything in the town - all its spoil - and enjoy the use of the spoil of your enemy, which the Lord your God gives you. Thus you shall deal with all the towns that lie very far from you, towns that do not belong to nations hereabout. In the towns of the latter peoples, however, which the Lord your God is giving you as a heritage, you shall not let a soul remain alive...lest they lead you into doing all the abhorrent things that they have done for their gods and you stand guilty before the Lord your God.

When in your war against a city you have to besiege it a long time in order to capture it, you must not destroy its trees, wielding the ax against them. You may eat of them, but you must not cut them down. Are trees of the field human to withdraw before you into the besieged city? Only trees that you know do not yield food may be destroyed; you may cut them down for constructing siegeworks against the city that is waging war on you, until it has been reduced.

The Torah's demand here that Israelites make an offer of peace before waging war is not what we will find in other Jewish sources - namely, a preference for peaceful resolutions of conflicts over what some might see as the glories of military conquest. Here the Torah is demanding only an offer of bloodless conquest and forced labor, which any army would prefer over the risk of losing their own lives in battle. Furthermore, the Torah allows for such bloodless conquest only for wars far off; 
the Israelites are commanded to kill every person in the Canaanite nations they are to occupy as their homeland.

Whether the later Rabbinic tradition interprets the Torah as it was originally meant is always, of course, open to question, but the Rabbis add limitations on how Jews should conduct war. So, for example, they interpret one verse of this Biblical passage to say this: "['When you approach a town] to attack it' - and not to make it suffer starvation or thirst and not to make it die the death of sicknesses." 42 As gruesome as war is, the Rabbis here are saying that outright killing is better than torturing people to death.

Furthermore, because the beginning of this Biblical passage is discussing wars against cities far off, beyond the conquest of Canaan, the Rabbis maintain that the exemptions from service at the very beginning of this passage apply only to such discretionary wars:

To what does this [the exemptions from service] apply? To discretionary wars [milhamot reshut], but in wars commanded by the Torah [milhamot mitzvah] all go forth, even a bridegroom from his chamber and a bride from her canopy. Rabbi Judah says: To what extent do these verses apply? To wars commanded by the Torah [milhamot mitzvah], but in obligatory wars [milhamot hovah] all go forth, even a bridegroom from his chamber and a bride from her canopy. ${ }^{43}$

Because this Mishnah introduces categories of war, the Talmud seeks to define them:

Rava said: All [i.e., the Rabbis of the majority opinion and Rabbi Judah] agree that the wars waged by Joshua to conquer Canaan [and the war against Amalek] were commanded; they also agree that the wars waged by the House of David for territorial expansion were voluntary; they differ with regard to wars [Israelites undertake] against heathens so that they shall not march against them. One [Rabbi Judah] calls them obligatory and the other [the majority opinion] voluntary, the practical issue being that one who is engaged in the performance of a commandment is exempt from the performance of another commandment. ${ }^{44}$

The Talmud thus describes three different kinds of wars: those directly commanded by God (milhamot mitzvah); discretionary wars to expand Israelite territory (milhamot reshut); and preemptive wars to defend against future attacks (milhamot hovah, obligatory wars). In other places the Talmud allows discretionary wars only with the concurrence of the Sanhedrin and an oracle issuing from the High Priest's breastplate, ${ }^{45}$ and thus when neither of those existed anymore, the only type of war allowed was a war not explicitly listed here but presumably assumed - namely, a war carried out in self-defense. The debate as to which wars are legitimate then narrows to the legitimacy of preemptive wars taken in the name of self-defense but before the Israelites were actually attacked:

Rav Judah stated in the name of Rav: If foreigners besieged Israelite towns, it is not permitted to sally forth against them or to desecrate the Sabbath in any other

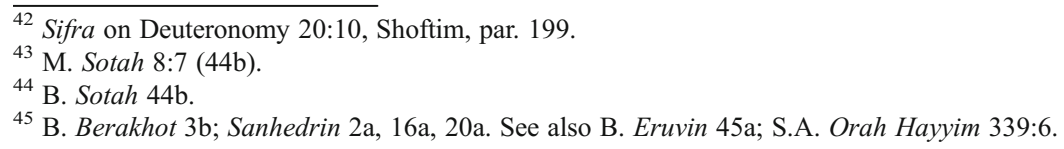


way on their account....This, however, applies only where they came for the sake of monetary gain, but if they came with the intention of taking lives, the people are permitted to sally forth against them with their weapons and to desecrate the Sabbath on their account. Where the attack, however, was made on a town that was close to the frontier [the loss of which would constitute a strategic danger to the other parts of the country], even though they did not come with any intention of taking lives but merely to plunder straw and hay, the people are permitted to sally forth against them with their weapons and to desecrate the Sabbath on their account. ${ }^{46}$

Furthermore, Rabbinic law requiring the approval of the Sanhedrin and, especially, the oracle of the High Priest's breastplate has been interpreted as requiring that Jews engage only in those battles that they have a good chance of winning; to do otherwise would violate the prominent Jewish norm of protecting and saving life. At the same time, Jewish laws forbidding idolatry and precedents in the Bible, the Maccabean period (the Hanukkah story as told in the Books of Maccabees), and the Middle Ages of Jews going to war or dying the death of martyrs to avoid idolatry would argue that some wars are necessary for that purpose even if the alternative exists to worship the idol and stay alive.

If Jewish sources give us some guidance in determining when to go to war, they provide precious little guidance as to the conduct of war. Sometimes the instructions one finds in the tradition are downright self-contradictory. So, for example, Deuteronomy 20, quoted above, requires Israelites to slay all of the enemy's men and permits Israelites to take as booty all of the enemy's women, children, and property. One story during Joshua's conquest, however, records a dramatic confrontation of those Israelites who took booty, and that same story was used during the Six Day War to publicly embarrass those few Israeli troops who took booty. ${ }^{47}$ King Saul is told to kill all the inhabitants of Amalek, women and children included, and to destroy all of its property, and he loses his throne because he follows the rule in Deuteronomy concerning booty. ${ }^{48}$ According to Biblical scholars, however, Deuteronomy was written some four centuries after King Saul, so this may be evidence of an evolving ethic of war rather than a contradiction within the sources. Deuteronomy 21 bans the destruction of fruit trees, as quoted above, and it also establishes rules about what Israelites must do if they wish to marry a woman taken captive.

Finally, and most importantly, the Jewish tradition does not valorize war. It sees self-defense and the avoidance of idolatry as making war necessary sometimes, and then it honors Jewish warriors who prevent or fend off enemy attacks. That is the context of seeing the ancient Maccabees and modern Israeli soldiers as heroes. War, though, is not to be desired, and it certainly is not to be honored as the way that a man shows that he is a man. On the contrary, the Rabbinic tradition, on which Judaism is based, honored the scholar and saw military might and even physical prowess as demonstrated in sports as a pagan, Roman value at odds with what Jews should prize. That, of course, may be because Jewish Zealots had tried to revolt against Rome several times and failed, and so the voices we are hearing in the Rabbinic tradition are

\footnotetext{
${ }^{46}$ B. Eruvin $45 \mathrm{a}$.

47 Joshua 7. The use of that story is recorded in The Seventh Day: Soldiers' Talk about the Six-Day War, Avraham Shapira, ed. (New York: Charles Scribner's Sons, 1970), pp. 74-75, 125-129.

48 Samuel 15.
} 
those who objected to war in the first place. Even if that historical explanation is true, however, the fact is that the Jewish tradition, while not completely pacifist, much prefers peace. Thus the Rabbis, citing the verse in Psalms that says "Seek peace and pursue it," say this:

The Law does not order you to run after or pursue the other commandments, but only to fulfill them on the appropriate occasion. But peace you must seek in your own place and pursue it even to another place as well. ${ }^{49}$

In addition peace is a major element in Jewish prayers; in fact, many of the major sections of the liturgy (e.g., the Amidah, Grace After Meals) end with a prayer for peace. Peace is also a major component of Jewish visions of the pinnacle of Jewish hopes, the Messianic era, perhaps most famously articulated in this passage from Isaiah:

In the days to come,

The Mount of the Lord's House

Shall stand firm above the mountains

And tower above the hills;

And all the nations

Shall gaze on it with joy.

And the many peoples shall go and say:

"Come, let us go up to the Mount of the Lord,

To the House of the God of Jacob;

That He may instruct us in His ways,

And that we may walk in His paths."

For instruction shall come forth from Zion,

The word of the Lord from Jerusalem.

Thus He will judge among the nations

And arbitrate for the many peoples,

And they shall beat their swords into plowshares

And their spears into pruning hooks:

Nation shall not take up sword against nation;

They shall never again know war. ${ }^{50}$

\footnotetext{
${ }^{49}$ J. Pe'ah 1:1. The verse cited is Psalms 34:15.

${ }^{50}$ Isaiah 2:2-4. Interestingly, Isaiah's younger contemporary, Micah, quotes him verbatim but then adds two lines that portray the Messianic world as one of theological pluralism rather than monotheism: "But every man shall sit under his grapevine or fig tree with no one to disturb him, for it was the Lord of Hosts who spoke. Though all the peoples walk each in the names of its gods, we will walk in the name of the Lord our God forever and ever." Micah 4:4-5.
} 


\section{Implications for a Modern Jewish Theory of War}

This essay has been based on the fact that the Jewish tradition's sources on war were either written very long ago (specifically, the First Temple period) or in contexts in which Jews did not have the authority or power to decide when to go to war or how to fight it. Despite this, I have been arguing that if one uses those sources with a strong degree of awareness of how their historical contexts differ from ours and combine them with Judaism's larger conceptions of God, the human being, and the goals of human life, one can formulate a modern theory of war and peace from within the Jewish tradition (rather than borrowing from outside sources) that is distinctly Jewish and yet modern. Now having examined those larger concepts and values, what emerges as at least some of the elements of a Jewish approach to war and peace? I would suggest the following pieces of such a theory:

A) Jus ad bellum: Justifications for going to war:

1) War sometimes must be fought. The Jewish concepts of both God and people understand them as sometimes making war.

2) Although conquest of territory justified war in the past, now only self-defense and avoidance of idolatry are acceptable reasons to go to war. Some wars will be clearly defensive in nature, but with the rise of terrorism, guerilla warfare, and hidden nuclear bombs and other weapons of mass destruction, sometimes the claim of the need to go to war for purposes of self-defense may be much harder to prove.

3) Self-defense may include pre-emptive strikes when the bellicose intention of the enemy is clear. This was certainly the case when Egypt's Nasser blocked the Straits of Tiran and publicly engaged in extensive saber-rattling in the days before the Six Day War; it proved not to be the case in President George W. Bush's invasion of Iraq to destroy the weapons of mass destruction that were supposed to be there but were not.

4) Jews should fight only in those wars that they are likely to win. This is a clear derivation from the demand to preserve our life and health as the property of God.

5) War should be avoided if at all possible; peace must be actively sought. This is articulated not only in a Rabbinic source that says this explicitly, but also in all the prayers and hopes of the Jewish tradition for a world without war. This is a culture that accepts war when necessary to defend oneself and honors those who succeed in that task, but not one that glorifies war as the way to prove a man's masculinity and a nation's power.

B) Jus in bello: Proper conduct of war.

1) Kill as few people as possible. Judaism's strong emphasis on protecting and saving life demands that even in a defensive war one must seek to kill as few people as possible. Even though Jewish leaders in Israel, and earlier under British Mandate, were mostly secular Jews, this element of the Jewish religious tradition undoubtedly influenced them in formulating the doctrine of tohar ha-neshek, "purity of arms," according to which soldiers may shoot only those who have first attacked them. This was clearly not the norm in the 
conquest of Canaan, when the Israelites were commanded to kill all the inhabitants, but that series of wars occurred some three thousand years ago and, most importantly, the rules governing those wars do not constitute precedents for any wars thereafter.

2) Preserve your own life and that of your comrades in arms. One has primary responsibility to protect and defend one's own life and those of one's comrades in arms and one's community. Therefore, even though one should seek to win by killing as few of the enemy as possible, one must kill as many as necessary in order to protect one's own life and those of one's army and community.

3) Damage the environment as little as possible. Hence the remarkable requirement in Deuteronomy to preserve the fruit trees, a requirement that can easily be applied to modern environmental concerns in war such as the use of Napalm in the Vietnam War.

4) War does not justify rape or other forms of torture, humiliation, or injury of the enemy not required to defend oneself and one's community. This stems directly from the respect that we must have for all human beings as creatures of God, created in the Divine Image. This leaves open the rare possibility recognized by the Israeli Supreme Court of some forms of physical pressure to reveal the whereabouts of terrorists about to kill many people (the "ticking bomb" case), but only if such procedures can be demonstrated to prevent such terrorism.

5) The norms with regard to booty and other forms of enemy property are unclear. This emerges from the conflicting norms found, on the one hand, in the Joshua and Saul stories, both of which see the taking of booty as unacceptable, and the law permitting the taking of booty in Deuteronomy, on the other.

These rules do not constitute a full-blown Jewish theory of just war, but they illustrate that such a theory can be built on the basis of Jewish precedents, concepts, and values. This does not preclude borrowing from other traditions, as Professor Walzer suggests, to supplement what we can learn from the Jewish tradition, but it does demonstrate that we need not satisfy ourselves with that, that we can build the foundation for a Jewish theory of war and peace - and judge which elements from outside the Jewish tradition we want to borrow - on the basis of what we find in Jewish sources. 